\title{
Hairy/Enhancer-Of-Split Related With YRPW Motif Protein 2
}

National Cancer Institute

\section{Source}

National Cancer Institute. Hairy/Enhancer-Of-Split Related With YRPW Motif Protein 2. NCI Thesaurus. Code C104540.

Hairy/enhancer-of-split related with YRPW motif protein 2 (337 aa, $36 \mathrm{kDa}$ ) is encoded by the human HEY2 gene. This protein is involved in both the negative regulation of gene expression and Notch-dependent signaling. 